\title{
WORKING ACROSS BORDERS: THE LIMITS OF LABOUR LAW FOR LOW-WAGE TEMPORARY MIGRANT WORKERS ${ }^{1}$
}

\author{
ARWEN JOYCE ${ }^{2}$
}

\begin{abstract}
A temporary migrant worker programme (TMWP) is a collection of laws, regulations and policies through which a receiving state regulates the entry, stay and treatment of low-wage temporary migrant workers. A worker employed through a TMWP can be understood to be engaged in a 'temporary migration project', that is, they are working abroad for a finite period of time in order to improve their status and welfare at home. The availability of low-cost labour generally entrenches demand for such workers in the receiving state's labour market and therefore the receiving state has an interest in continuing to attract them. In order to do so, workers must be able to successfully complete their temporary migration projects. However, TMWP policies often create opportunities for exploitation and disempowerment related to low-wage temporary migrant workers' precarious residence status, weak financial position and dependence on their employers, that jeopardise the normative defensibility and sustainability of such programmes. Using examples from Singapore, Hong Kong and South Korea, this paper argues that evidence of conventional labour law remedies in a receiving state is necessary but not sufficient to enable temporary migrant workers to successfully complete their temporary migration projects. The underlying purpose of labour law and the limitations of its application to this group of workers are considered along with some unique sources of their vulnerability. The paper concludes that in order to make TMWPs more normatively defensible and sustainable, receiving states should address the root causes of low-wage temporary migrant workers' vulnerability when formulating TMWP laws and policies.
\end{abstract}

KEYWORDS: Labour migration; labour law theory; temporary migrant workers.

\footnotetext{
${ }^{1}$ A version of this paper was originally presented in the "Exploring Legal Borderlands" stream at the Socio-Legal Studies Association Conference, University of Leeds, April 2019. Thanks to the stream participants, stream organisers and two anonymous reviewers for their helpful comments. Thanks also to Bernard Ryan and Lisa Rodgers for their PhD supervision and comments on an earlier draft.

2 PhD Candidate and Graduate Teaching Assistant, Leicester Law School, University of Leicester. Contato: aej12@le.ac.uk
} 


\section{INTRODUCTION}

A temporary migrant worker programme (TMWP) is a collection of laws, regulations and policies through which a receiving state regulates the entry, stay and treatment of low-wage temporary migrant workers. ${ }^{3}$ Over 50 states operate temporary migrant worker programmes ${ }^{4}$ and it is estimated that one-third or more of the world's 110 million migrant workers are employed through such programmes. ${ }^{5}$ The purpose of such arrangements is to bring low-cost workers into a labour market on a non-permanent basis. For employers in the receiving state, this labour is 'low-

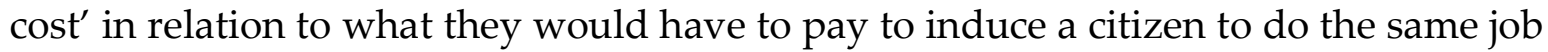
but for the workers the offered wage is generally much higher than it would be possible for them to earn at home.

TMWPs are designed with the expectation that low-wage temporary migrant workers will not settle permanently in the receiving state and as such do not generally permit workers to stay past the expiration of their work permits or to bring their families with them. In addition, temporary migrant workers may not be permitted to participate in or benefit from social programmes in the receiving state like subsidised retirement savings or unemployment protection. As a result, a worker employed through a TMWP can be understood to be engaged in a temporary migration project', ${ }^{6}$ that is, they are working abroad for a finite (but not necessarily brief) period of time in order to improve their status and welfare at home. ${ }^{7}$

Although TMWPs are designed to rotate and replace temporary workers with new recruits on a regular basis, the availability of low-cost labour generally entrenches demand for such workers in the receiving state's labour market. So, as a group, these workers are considered desirable and necessary on an on-going basis and the receiving state has an interest in continuing to attract them. However,

${ }^{3}$ Such programmes differ from arrangements that allow workers to move within a visa-free zone, e.g. from one EU state to another. Undertaking a temporary migration project of the type discussed herein requires visa approval from a receiving state.

${ }^{4}$ Kristin Surak, 'Guestworkers: A Taxonomy' (2013) 44 New Left Review 84, 84.

5 Philip Martin, 'Guest or Temporary Foreign Worker Programs', Handbook of the Economics of International Migration (Volume 1A, 2015) 718.

${ }^{6}$ I borrow this term from Ottonelli and Torresi. See Valeria Ottonelli and Tiziana Torresi, 'Inclusivist Egalitarian Liberalism and Temporary Migration: A Dilemma' (2012) 20 The Journal of Political Philosophy 202; Valeria Ottonelli and Tiziana Torresi, 'Temporary Migration Projects and Voting Rights' (2014) 17 Critical Review of International Social and Political Philosophy 580.

7 While a useful framework for the purposes of this analysis, this definition is admittedly a gross overgeneralization and oversimplification of the myriad motivations a migrant might have, economic and otherwise, for seeking temporary employment abroad. For the avoidance of doubt, a trafficking victim would not be considered to be undertaking a temporary migration project. 
TMWPs are generally 'designed to serve the labour market of the receiving country, rather than the plans of migrants ${ }^{8}$ and therefore are not likely to prioritise the successful completion of a temporary migration project. This disconnect often results in TMWPs that create opportunities for exploitation and disempowerment, which in turn jeopardise the normative defensibility and sustainability of such programmes. In other words, despite evidence of conventional labour law remedies in a receiving state, temporary migrant workers may find themselves in exploitative employment relationships that meet the International Labour Organization's definition of forced labour..$^{9}$ And for the reasons discussed herein, it may be very difficult for the worker to end such an employment relationship or seek redress.

A related challenge for policymakers is the fact that potentially harmful labour market features identified by labour law theorists such as dependency and an imbalance in bargaining power are exacerbated for low-wage temporary migrant workers. The legal structure of a typical TMWP and the underlying economic factors that create and sustain these labour migration flows combine to create a severe power imbalance related to low-wage temporary migrant workers' precarious residence status, weak financial position and dependence on their employers. ${ }^{10}$ As a result, the employment-related challenges experienced by low-wage temporary migrant workers cannot be adequately addressed through the application of conventional labour law remedies alone. In other words, even in a receiving state that has passed protective labour laws that on their face apply to temporary migrant workers and where temporary migrant workers have the opportunity to form or join a labour union, such workers may be unable to access these protections in practice or to engage in productive collective bargaining with employers. It is therefore useful to go beyond an assessment of whether conventional labour law remedies exist in a receiving state and instead to assess whether such remedies are achieving labour law's underlying goals for this group of workers given the unique drivers of their vulnerability.

In setting out this argument, this paper will first recall the underlying purpose of labour law and consider the limitations of the application of its conventional remedies to this group of workers. It will then outline some of the primary sources of low-wage temporary migrant workers' vulnerability using examples from Singapore, Hong Kong and South Korea with a view to proposing TMWP policy reforms. In

${ }^{8}$ Ottonelli and Torresi, ‘Temporary Migration Projects and Voting Rights' (n 4) 595.

9 International Labour Organization, Forced Labour Convention, 1930 (No. 29), Article 2(1).

${ }^{10}$ See Mimi Zou, 'The Legal Construction of Hyper-Dependence and Hyper-Precarity in Migrant Work Relations' (2015) 31 The International Journal of Comparative Labour Law and Industrial Relations 141. 
short, it is argued that while the existence of conventional labour law remedies in a receiving state is necessary to protect temporary migrant workers' labour rights, on their own such remedies are insufficient. This paper concludes that in order to make TMWPs more normatively defensible and sustainable, receiving states should consider whether and to what extent the underlying goals of conventional labour law theory are being achieved for this group of workers. This would enable policy makers and reformers to better assess whether TMWP laws and policies are adequately addressing the root causes of low-wage temporary migrant workers' vulnerability. ${ }^{11}$

\section{UNDERLYING PRINCIPLES AND GOALS OF LABOUR LAW}

Sinzheimer, the founding father of German labour law, observed that human dignity may be endangered by the employment relationship. ${ }^{12}$ Similarly, Langille and others have argued - echoing Kant and Sen - that labour should not be treated solely as a commodity because the ultimate object of the transaction in an employment relationship is a human being. ${ }^{13}$ Sinzheimer also observed that dependency is a feature of the employment relationship and it follows that unfair treatment, exploitation and subordination can flow from that dependency. ${ }^{14}$

Building on these observations, Davidov identifies some general goals ascribed to labour law at three different levels of abstraction. ${ }^{15}$ The first level concerns the overarching values that labour law is said to promote, such as autonomy, human dignity and distributive justice. ${ }^{16}$ At the second level, Davidov identifies characteristics of the labour market that labour law may seek to counteract, such as inequality of bargaining power, market failures and the commodification of labour. ${ }^{17}$ Finally, on an interpersonal level, labour law may aim to address aspects of the

\footnotetext{
${ }^{11}$ Sending states also bear responsibility for the protection of their nationals working abroad but this paper focuses on temporary migrant workers' labour rights and relationships in the receiving state as that is where their employers are located and where their employment-related challenges occur.

${ }_{12}$ Ruth Dukes, 'Hugo Sinzheimer and the Constitutional Function of Labour Law', The Idea of Labour Law (Oxford University Press 2011) 57.

${ }^{13}$ Brian Langille, 'Labour Law's Theory of Justice', The Idea of Labour Law (Oxford University Press 2011) 114.

${ }^{14}$ Manfred Weiss, 'Re-Inventing Labour Law?', The Idea of Labour Law (Oxford University Press 2011) 43.

${ }^{15}$ Guy Davidov, A Purposive Approach to Labour Law (Oxford University Press 2016) 13-33.

16 ibid 31.

17 ibid.
} 
employment relationship that disadvantage workers such as subordination and dependency. ${ }^{18}$

Labour law's basic goals, therefore, include protecting workers' material needs, addressing the imbalance in bargaining power between employers and workers in general, and reducing a specific worker's dependency on their employer. The two conventional labour law tools or remedies that have been proposed to accomplish these basic goals are the collectivization of workers to increase their bargaining power (a procedural constraint on employers) and protective legislation to safeguard workers' material and physical needs (a substantive constraint on employers). As Weiss explains,

In the $19^{\text {th }}$ century it became evident that the competition between individual employees at the labour market was a race to the bottom and that only collectivization of employees combined with protective legislation could prevent this destiny. ${ }^{19}$

Davidov adds, 'the asymmetry created by democratic deficits [in the workplace puts] workers in a position of vulnerability that justifies regulatory intervention to protect them' ${ }^{20}$ and 'collective bargaining can be justified on several different grounds [including the promotion of] workplace democracy, redistribution, and efficiency. ${ }^{21}$

Substantive and procedural constraints on employers are especially beneficial for workers who cannot effectively self-insure or spread the economic risk of the loss of their employment. ${ }^{22}$ Such a worker 'generally has no choice but to depend and rely on the employer, on its solvency and on the continued payment of wages. ${ }^{23}$ Thus, Davidov concludes, 'work relations that involve a relatively high level of economic dependency, in the sense of inability to spread risks, require regulatory intervention and protection. ${ }^{24}$ However, as will be argued next, regulatory intervention in the form of protective legislation in the receiving state and an opportunity to join or form labour unions are necessary but not sufficient conditions to overcome the employment-related challenges faced by temporary migrant workers.

18 ibid.

${ }^{19}$ Weiss (n 12) 43-44.

${ }^{20}$ Davidov (n 13) 42.

21 ibid 86.

22 See ibid 47.

23 ibid.

24 ibid 48. 


\section{Application of labour law theory to TMWPs}

As a field of scholarship, labour law has historically focused on issues emerging from the employment relationship and the inherent inequality of bargaining power between the employer and worker. ${ }^{25}$ Legal issues that arise in the broader labour market context-including addressing how a state should source workers from abroad, and how best to protect non-citizen workers' labour rights and interestshave been less of a focus. In addition, while we may be able to articulate the original pro-labour goals of labour law, in practice the development of labour law systems are driven by a range of overlapping and sometimes conflicting policy interests. ${ }^{26}$

Theorists have observed that not only do labour law systems seek to fulfil a complex range of objectives, but those objectives may change over time. ${ }^{27}$ As an example, Goldin notes that in civil law countries in Western Europe in recent decades, labour laws have been repeatedly reformed to align with economic goals such as efficiency, labour market flexibility and the promotion of corporate prosperity. ${ }^{28}$ These objectives did not originally animate Continental labour law systems and the reforms have arguably weakened 'the intensity of protective legal systems' for workers. ${ }^{29}$

Thus, although Western labour law scholarship has historically focused on labour law's potential to protect and empower workers, these goals may be overshadowed by competing objectives such as maintaining a particular social order, maintaining political control and/or promoting economic development. A focus on achieving these objectives may, directly or indirectly, displace other priorities such as protecting workers' rights (especially when the workers are non-citizens) and promoting justice and fairness in the labour market. As Goldin explains, while the basic idea of labour law may be fairly universal, 'different "particular ideas" of labour law [are] identifiable in every legal regime.'30

The structure of a state's labour law system is necessarily the result of legislative priorities and preferences. When structuring a TMWP, many states prioritise private law rights and economic development over the labour rights of low-wage temporary

${ }^{25}$ Sean Cooney and others (eds), Law and Labour Market Regulation in East Asia (Routledge 2002) 2.

${ }^{26}$ Adrián Goldin, 'Global Conceptualizations and Local Constructions of the Idea of Labour Law', The Idea of Labour Law (Oxford University Press 2011) 70.

27 Paul Davies and Mark Freedland, Kahn-Freund's Labour and the Law (Third, 1983) 5-6; Cooney and others (n 23) 2.

${ }^{28}$ Goldin (n 24) 73.

29 ibid.

30 ibid 71. 
migrant workers. ${ }^{31}$ As such, TMWPs are typically designed to promote economic efficiency and avoid oppositional labour movements instead of to accomplish the pro-labour goals enumerated by labour law theorists. For example, helping employers contain their labour costs may be prioritised over the competing policy goal of ensuring a living wage is paid to the labour market's lowest earners. It may be difficult to convince states to reform their TMWP or to better enforce pro-labour laws already in place for temporary migrant workers when such an approach does not align with the state's current political or economic priorities.

Nevertheless, receiving states may be open to TMWP policy reform if it is argued that absent such reforms they will lose access to low-cost non-citizen labour. Receiving states have an interest in designing a TMWP that is both normatively defensible and sustainable and therefore an interest in eliminating the opportunities for deception and exploitation in the recruitment process, and disempowerment within the employment relationship, that erode the economic benefits of undertaking a temporary migration project.

\section{Labour law remedies and low-wage temporary migrant workers}

The two main tools advanced by conventional labour law theory to protect workers and improve their bargaining power do not operate effectively for temporary migrant workers and are therefore insufficient to enable such workers to successfully complete their temporary migration projects. The effectiveness of procedural and substantive and constraints on the employers of temporary migrant workers will now be considered in turn using examples from Singapore, Hong Kong and South Korea.

\subsection{Collectivisation of workers: a procedural constraint on employers}

In many states with TMWPs, joining labour movements and staging industrial action are not realistic or effective options for non-citizen workers. In Singapore, lowwage temporary migrant workers in the construction industry are allowed to join the industry's trade union but industrial relations in Singapore are 'characterized by a high degree of state intervention, particularly in controlling...collective bargaining in order to provide modestly priced and disciplined workers. ${ }^{32}$ But even in states such as Hong Kong and South Korea where temporary migrant workers do join and form

\footnotetext{
${ }^{31}$ See Martin Ruhs, The Price of Rights: Regulating International Labor Migration (Princeton University Press 2013).

${ }^{32}$ Nicola Piper, 'Migrant Worker Activism in Singapore and Malaysia: Freedom of Association and the Role of the State' (2006) 15 Asian and Pacific Migration Journal 359, 365.
}

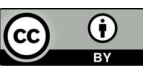


trade unions, such unions are unlikely to represent an effective procedural constraint on employers. The Migrant Trade Union in South Korea, for example, engages in 'advocacy work to protect and improve migrant workers' rights [and] grassroots organizing ...to educate and empower migrant workers [but its activities remain] largely separate from the activities of its mainstream [labour union] affiliates. ${ }^{33}$ In Hong Kong, temporary migrant workers can join labour unions and participate in political protests but 'unions have little industrial leverage because they have no right to engage in collective bargaining'. ${ }^{34}$ Therefore, neither the existence of a migrant-specific trade union nor the ability of temporary migrant workers to join a trade union for their industry ensures that temporary migrant workers will be able to engage in or benefit from collective bargaining.

\subsection{Protective legislation: a substantive constraint on employers}

Turning to substantive constraints on employers, the extent to which a low-wage temporary migrant worker is covered by protective labour legislation in the receiving state where they work varies widely. In South Korea for example, basic constitutional protections such as equal protection and non-discrimination under the law and basic protective labour legislation including a minimum wage apply to all workers. In Singapore, protective, generally applicable employment laws also apply to low-wage temporary migrant workers in the construction and marine industries but not to livein foreign domestic workers. Importantly, even when substantive labour law protections such as maximum working hours, overtime pay and mandatory rest days do apply to temporary migrant workers they are difficult to invoke and enforce due to such workers' limited and dependent immigration status. For this reason, it is argued that such protections can never be adequate as long as the sources of these workers' reduced bargaining power persist.

\section{SOURCES OF VULNERABILITY FOR LOW-WAGE TEMPORARY MIGRANT WORKERS AND OPPORTUNITIES FOR TMWP POLICY REFORM}

Having recalled the underlying purpose of labour law and considered the limitations of the application of its conventional remedies to low-wage temporary migrant workers, this section examines the primary sources of temporary migrant

${ }_{33}$ Michele Ford, From Migrant to Worker: Global Unions and Temporary Labor Migration in Asia (Cornell University Press 2019) 129.

34 ibid 31. 
workers' vulnerability with a view to proposing TMWP policy reforms. Low-wage temporary migrant workers are more vulnerable and have less bargaining power in their employment relationships than similarly situated citizen workers for three primary reasons, all of which are related to their precarious and dependent visa status as non-citizen workers.

First, temporary migrant workers often commence a temporary migration project with a significant amount of migration debt due to paying recruitment and other fees to labour market intermediaries. Second, the labour market mobility of temporary migrant workers is often severely limited in the receiving state. Finally, it is more difficult for temporary migrant workers than citizen workers to access the civil justice system in the receiving state in a meaningful way. Filing a labour court case or a civil claim often takes a long time and comes at a high cost, and the worker may be deported before their case is resolved.

Together, these three sources of vulnerability combine to construct workers who, upon choosing to undertake a temporary migration project outside of their home state, have a significant debt to repay, have very little chance of finding alternative employment in the receiving state if they leave their first job, and have no meaningful chance of being able to sue their employer if they are mistreated or exploited. The discussion that follows looks at these three drivers of vulnerability in more detail.

\section{Recruitment-related migration debt}

Rising recruitment costs are a major source of vulnerability for temporary migrant workers. ${ }^{35} \mathrm{~A}$ significant driver of such costs is the involvement of private firms in the recruitment process (primarily but not exclusively in the sending state) including recruiters, training centres, testing centres and employment agents. As a result, temporary migrant workers often arrive in the receiving state with a significant amount of migration debt. The higher the migration costs borne by a temporary migrant worker, the longer they will have to work to successfully complete their temporary migration project and therefore the greater the chances that their project could be derailed by a workplace injury, their employer's bankruptcy, or another employment interruption outside of their control.

\footnotetext{
35 The Bangladesh Annual Migration Report 2018 notes that migration costs for Bangladeshi migrant workers in Saudi Arabia increased by 32 to 38 times since 1985 while the average monthly income of temporary migrant workers in that country has only gone up by two to four times in the same period. Mehedi Al Amin, 'Workers' Migration Cost 450\% Higher than Government Rate' Dhaka Tribune (Dhaka, 25 May 2019) <https://www.dhakatribune.com/business/2019/05/25/workersmigration-cost-450-higher-than-government-rate> accessed 29 May 2019.
} 
Some states have capped the amount that can be charged by an employment agency within their borders but maintain that recruitment fees paid abroad are beyond their jurisdiction. ${ }^{36}$ However, the demand for recruitment-related services exists because many receiving states outsource the selection of suitable workers to the employers themselves. When faced with a large pool of potential workers in multiple designated sending states, employers rely on middlemen to screen and select workers. Under these conditions, markets develop whereby jobs are given to workers who agree to pay the highest fees, instead of to workers who have the most aptitude or relevant experience for a given job.

Entering into memoranda of understanding (MOUs) or bilateral labour agreements with sending states is one way receiving states can try to ensure that governments - and not third-party agents-are managing the temporary migrant worker recruitment process. Such agreements vary considerably in length, coverage and the extent to which they are legally binding, but typically address how workers are screened and trained in the sending state, the obligations of the receiving state government and employers with respect to the treatment of temporary migrant workers, and how employment disputes will be addressed.

South Korea has demonstrated that recruitment costs can be greatly reduced through direct government oversight and regulation of the recruitment process. In 2004, South Korea implemented a new TMWP called the Employment Permit System and has since established MOUs with 16 sending states. ${ }^{37}$ The government has stated that it implements such agreements 'to prevent corruption scandal[s] in the sending process'.$^{38}$ In other words, to stop the exploitation of temporary migrant workers by labour market intermediaries (and by extension, employers) during the recruitment stage of a temporary migration project. Each MOU contains provisions designed to enhance transparency and efficiency in the sending process and maintain cooperation between the two governments after the foreign worker enters South Korea. ${ }^{39}$ Under these MOUs, sending states agree to manage the selection of qualified

36 Mauro Testaverde and others, Migrating to Opportunity: Overcoming Barriers to Labor Mobility in Southeast Asia (World Bank 2017) 220; Singapore Ministry of Manpower, 'MOM Regulates Local Recruitment Fees; Penalises Errant Agencies' (2012) <http://www.mom.gov.sg/newsroom/pressreplies/2012/mom-regulates-local-recruitment-fees-penalises-er> accessed 31 May 2019.

37 Young-bum Park (ed), Low-Skilled Temporary Foreign Worker Schemes in Selected Asian Countries with a Special Reference to Korea's Employment Permit System (Human Resources Development Service of Korea 2017) 10.

38 South Korea Ministry of Employment and Labor, 'Overview: Procedure on Selection and Introduction of Foreign Worker (E-9)' (2015) <https://www.eps.go.kr/ph/index.html> accessed 31 May 2019.

39 Young-bum Park and Myung-hui Kim, Korea's Temporary Low-Skilled Foreign Worker Program: Employment Permit System (Human Resources Development Service of Korea 2015) 162.

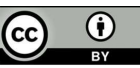


workers based on objective standards, such as the ability to pass a Korean language test and previous work experience or skills training. ${ }^{40}$

According to the South Korean government, in 2001 before the Employment Permit System was implemented, the average recruitment cost per temporary migrant worker in South Korea was US\$3,509; by 2014 the cost per worker had dropped to US $\$ 941 .{ }^{41}$ Sending states are incentivized to comply with the terms of their MOU lest South Korea reduce the quota of workers drawn from that state. Transient Workers Count Too (TWC2), an NGO based in Singapore, calls this achievement 'both uncommon and remarkable, especially in the context of global governmental and regulatory apathy towards recruitment fees and the unfettered actions of exploitative recruitment agencies that characterise the global migrant labour market.' ${ }^{42}$ States may be reluctant to spend the resources required to oversee the recruitment process in this manner but a dramatic reduction in recruitmentrelated migration costs for low-wage temporary migrant workers increases the chances that they will be able to successfully complete their temporary migration projects and therefore increases the normative defensibility and sustainability of a TMWP.

\section{Labour market mobility}

The possibility for a temporary migrant worker to change industries, employers or even jobs once in the receiving state is often severely limited by TMWP policies. This is the case in Hong Kong and Singapore (and in many Gulf States), which have implemented kafala-type visa sponsorship systems for low-wage temporary migrant workers. Such workers are issued with a work permit of limited duration that is tied to a specific employer, ${ }^{43}$ can be cancelled by the employer at will, and is generally not transferrable to a different employer without the consent of the original employer

${ }^{40}$ South Korea Ministry of Employment and Labor (n 36).

${ }^{41}$ Park and Kim (n 37) 162-63. Fees paid by potential migrant workers to private Korean language schools in sending states are not included in this computation. Jiang Haolie and Monika Roszkowska, 'Research Brief: Migrant Worker Recruitment Costs, South Korea' (2017) 4 <http://twc2.org.sg/wp-content/uploads/2017/04/South-Korea-Recruitment-Fees.pdf> accessed 21 May 2019.

${ }^{42}$ Haolie and Roszkowska (n 39) 5.

${ }^{43}$ See Singapore Ministry of Manpower, 'Key Facts on Work Permit for Foreign Worker' (2018) $<$ http://www.mom.gov.sg/passes-and-permits/work-permit-for-foreign-worker/key-facts> accessed 31 May 2019. 
and/or the receiving state's labour ministry. ${ }^{44}$ In Hong Kong, a foreign domestic worker must leave Hong Kong within two weeks after the termination of their contract. ${ }^{45}$ In Singapore, the Ministry of Manpower reports that 2,200 low-wage temporary migrant workers, out of an estimated 13,500 who filed salary claims against their employers between 2014 and 2017, were granted permission to change employers. ${ }^{46}$

In South Korea, temporary migrant workers employed under the Employment Permit System can change employers within the same sector up to three times during their stay with the permission of their employer, or an unlimited number of times if they can provide proof of mistreatment. ${ }^{47}$ TWC2 notes that the ability of temporary migrant workers in South Korea to change jobs 'radically rebalances the dynamics of power between worker and employer, as it curbs the ability of employers to extract kickbacks for continued employment, to abuse workers with impunity and to threaten workers with termination of employment or forced repatriation.' ${ }^{48}$ However, a World Bank Group report on South Korea's TMWP cautions that employers are not inclined to give permission for a temporary migrant worker to leave as it may reduce their eligibility to hire workers through the Employment Permit System in the future and obtaining sufficient proof of abuse is also a challenge. ${ }^{49}$

Receiving states may be reticent to increase the labour market mobility of temporary migrant workers if they fear this will result in more workers overstaying their visas or because outsourcing the monitoring of workers' visa status to employers relieves states of an administrative and financial burden. But an inability to change jobs in the receiving state if faced with an exploitative or insolvent employer drastically reduces temporary migrant workers' bargaining power and therefore undermines their ability to successfully complete a temporary migration project.

44 Tamera Fillinger and others, 'Labour Protection for the Vulnerable: An Evaluation of the Salary and Injury Claims System for Migrant Workers in Singapore' (2017) 12 <http://twc2.org.sg/wpcontent/uploads/2017/06/labour_protection_for_the_vulnerable.pdf> accessed 31 May 2019.

45 Hong Kong Immigration Department, 'Foreign Domestic Helpers' (2012) <https://www.immd.gov.hk/eng/faq/foreign-domestic-helpers.html\#employment> $\quad$ accessed 28 August 2019.

46 Singapore Ministry of Manpower, 'Foreign-Worker Salary Disputes Are Dealt with Speedily: MOM' (2017) <http://www.mom.gov.sg/newsroom/press-replies/2017/0224-foreign-worker-salary-disputesare-dealt-with-speedily> accessed 31 May 2019.

47 Yoonyoung Cho and others, 'Bilateral Arrangement of Temporary Labor Migration: Lessons from Korea's Employment Permit System' (2018) 64.

${ }^{48}$ Haolie and Roszkowska (n 39) 6.

${ }^{49}$ Cho and others (n 45) 64-65.

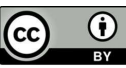




\section{Access to justice}

It is generally more difficult for temporary migrant workers than citizen workers to access the civil justice system in the receiving state in a meaningful way. Under some TMWPs, employment-related disputes are referred automatically to arbitration or handled in camera by a labour tribunal and proceedings may be conducted without the support of a legal representative or a translator.$^{50}$ If the worker files a civil claim, this often comes at a high cost and legal aid may not be granted to noncitizen claimants. In addition, civil cases may take a year or longer to resolve and the worker may not be granted a new work visa for the period during which their claim is being adjudicated. For example, when a temporary migrant worker in Singapore files an employment-related claim against their employer, the Ministry of Manpower will issue them with a Special Pass card, which regularises their stay in the country for the duration of their claim but does not permit them to work. ${ }^{51}$ Finally, the worker may be deported or choose to return home before their case is resolved and pursuing justice in the receiving state from a distance may be difficult or impossible.

Limiting temporary migrant workers' access to justice in the receiving state undermines workers' ability to successfully complete their temporary migration projects. This is the case when, for example, a workplace injury or an employer's insolvency results in the premature termination of a worker's visa. In such situations, TMWP regulations often require employers to maintain adequate insurance to cover workers' costs or pay out damages as appropriate, but when temporary migrant workers are not able to meaningfully pursue employment-related claims, unscrupulous employers are unlikely to feel compelled to incur such costs.

One way to enable temporary migrant workers to pursue civil claims against an exploitative, uncooperative or insolvent employer while also successfully completing their temporary migration projects is to increase their labour market mobility so that they can pursue other employment opportunities while waiting for their claim to be resolved. In addition, receiving states should consider ways to increase access to justice for temporary migrant workers who would prefer to return home before their employment-related claim is resolved. In March 2019, Hong Kong's Labour Tribunal granted a temporary migrant worker's request to continue to pursue her wrongful dismissal claim from her home state of the Philippines via video conferencing

50 Fillinger and others (n 42) 30; Andrew Gardner, Silvia Pessoa and Laura Harkness, 'Labour Migrants and Access to Justice in Contemporary Qatar' (2014) 6 <http://eprints.lse.ac.uk/60241> accessed 31 May 2019.

51 Singapore Immigration and Checkpoints Authority, 'Special Pass Card' (2019) <https://www.ica.gov.sg/news-and-publications/public-education/special-pass-card> accessed 28 August 2019. 
software. ${ }^{2}$ Utilising technology in creative ways can create opportunities to empower and protect the rights of low-wage temporary migrant workers.

\section{CONCLUSION}

Even in states with protective labour laws and active labour unions, low-wage temporary migrant workers are vulnerable to mistreatment and exploitation. The harmful labour market and employment-related features identified by labour law theory are exacerbated for low-wage temporary migrant workers, who suffer from limited bargaining power and an inability to effectively spread the economic risk of the loss of their employment. However, the existence of conventional labour law remedies in a receiving state is not, on its own, adequate to protect this group of workers given their precarious and dependent immigration status. Specifically, a lack of oversight of the recruitment process and overly restrictive immigration regulations undermine temporary migrant workers' ability to successfully complete their temporary migration projects.

If receiving states want to continue to import low-cost temporary migrant labour through TMWPs, such programmes need to be designed so as not to undermine workers' ability to successfully complete a temporary migration project. After investing so much financially and otherwise for the opportunity to work overseas, a low-wage temporary migrant worker will be understandably reluctant to cut short their temporary migration project. Therefore, they will be reticent to raise concerns about mistreatment or late salary payment even when a receiving state's labour law prohibits these infractions. In a system that ties workers to a single employer through a work permit that can be cancelled at will, a worker that raises a health and safety issue or complains about a missed salary payment can be easily replaced with another worker who is more compliant. Given the unequal bargaining power between the parties, receiving states cannot rely on employers to treat workers fairly and comply with protective labour legislation absent routine investigation and enforcement.

In addition, if a worker raises a concern about an employer to the relevant labour ministry, the result may be that the employer is investigated and punished or fined but it will also likely result in the deportation of their non-citizen workers. A worker who has a large recruitment-related debt to pay and has only been working in the receiving state for a short time has an economic incentive to delay reporting employment contract-related infractions to the labour ministry. It is in his or her interest to continue working and to hope that the employer will eventually correct

${ }^{52}$ Justice Without Borders, 'Justice in Hong Kong Finally Comes to Those Back Home' (2019) $<$ http://forjusticewithoutborders.org/justice-in-hong-kong-finally> accessed 29 March 2019. 
the infraction rather than report the situation and forfeit future earnings. As a result, receiving states cannot rely on temporary migrant workers to report such infractions, as doing so will tend to result in the premature termination of their temporary migration projects.

It is in receiving states' interest to address the disempowerment and vulnerability that arise as a result of low-wage temporary migrant workers' weak financial position, precarious residence status and dependence on their employers. Changes in TMWP policy, such as efforts to reduce recruitment fees and increase labour market mobility for temporary migrant workers in South Korea, and the Hong Kong Labour Tribunal's decision to allow a temporary migrant worker who has returned home to testify using video conferencing software, address some of the root causes of such workers' vulnerability and therefore have the potential to improve the protection of temporary migrant workers' labour rights. TMWP laws, policies and proposals for reform should be similarly assessed in light of their ability to achieve labour law's underlying goals for this group of workers. Doing so would increase temporary migrant workers' chances of success when embarking on temporary migration projects and make TMWPs more normatively defensible and sustainable.

\section{REFERENCES}

Al Amin M, 'Workers' Migration Cost 450\% Higher than Government Rate' Dhaka Tribune (Dhaka, 25 May 2019)

$<$ https://www.dhakatribune.com/business/2019/05/25/workers-migration-cost-450higher-than-government-rate> accessed 29 May 2019.

Cho Y and others, 'Bilateral Arrangement of Temporary Labor Migration: Lessons from Korea's Employment Permit System' (2018).

Cooney S and others (eds), Law and Labour Market Regulation in East Asia (Routledge 2002).

Davidov G, A Purposive Approach to Labour Law (Oxford University Press 2016).

Davies P and Freedland M, Kahn-Freund's Labour and the Law (Third, 1983).

Dukes R, 'Hugo Sinzheimer and the Constitutional Function of Labour Law', The Idea of Labour Law (Oxford University Press 2011). 
Fillinger T and others, 'Labour Protection for the Vulnerable: An Evaluation of the Salary and Injury Claims System for Migrant Workers in Singapore' (2017) $<$ http://twc2.org.sg/wpcontent/uploads/2017/06/labour_protection_for_the_vulnerable.pdf $>$ accessed 31 May 2019.

Ford M, From Migrant to Worker: Global Unions and Temporary Labor Migration in Asia (Cornell University Press 2019).

Gardner A, Pessoa S and Harkness L, 'Labour Migrants and Access to Justice in Contemporary Qatar' (2014) <http://eprints.lse.ac.uk/60241> accessed 31 May 2019.

Goldin A, 'Global Conceptualizations and Local Constructions of the Idea of Labour Law', The Idea of Labour Law (Oxford University Press 2011).

Haolie J and Roszkowska M, 'Research Brief: Migrant Worker Recruitment Costs, South Korea' (2017) <http://twc2.org.sg/wp-content/uploads/2017/04/South-KoreaRecruitment-Fees.pdf $>$ accessed 21 May 2019.

Hong Kong Immigration Department, 'Foreign Domestic Helpers' (2012) $<$ https://www.immd.gov.hk/eng/faq/foreign-domestic-helpers.html\#employment> accessed 28 August 2019.

International Labour Organization, 'Forced Labour Convention, 1930 (No. 29).

Justice Without Borders, 'Justice in Hong Kong Finally Comes to Those Back Home' (2019) <http://forjusticewithoutborders.org/justice-in-hong-kong-finally> accessed 29 March 2019.

Langille B, 'Labour Law's Theory of Justice', The Idea of Labour Law (Oxford University Press 2011).

Martin P, 'Guest or Temporary Foreign Worker Programs', Handbook of the Economics of International Migration (Volume 1A, 2015). 
Ottonelli V and Torresi T, 'Inclusivist Egalitarian Liberalism and Temporary Migration: A Dilemma' (2012) 20 The Journal of Political Philosophy 202.

- - ,'Temporary Migration Projects and Voting Rights' (2014) 17 Critical Review of International Social and Political Philosophy 580.

Park Y (ed), Low-Skilled Temporary Foreign Worker Schemes in Selected Asian Countries with a Special Reference to Korea's Employment Permit System (Human Resources Development Service of Korea 2017).

Park Y and Kim M, Korea's Temporary Low-Skilled Foreign Worker Program: Employment Permit System (Human Resources Development Service of Korea 2015).

Piper N, 'Migrant Worker Activism in Singapore and Malaysia: Freedom of Association and the Role of the State' (2006) 15 Asian and Pacific Migration Journal 359.

Ruhs M, The Price of Rights: Regulating International Labor Migration (Princeton University Press 2013).

Singapore Immigration and Checkpoints Authority, 'Special Pass Card' (2019) $<$ https://www.ica.gov.sg/news-and-publications/public-education/special-pass-card> accessed 28 August 2019.

Singapore Ministry of Manpower, 'MOM Regulates Local Recruitment Fees; Penalises Errant Agencies' (2012) <http://www.mom.gov.sg/newsroom/pressreplies/2012/mom-regulates-local-recruitment-fees-penalises-er> accessed 31 May 2019.

_- , 'Foreign-Worker Salary Disputes Are Dealt with Speedily: MOM' (2017) $<$ http://www.mom.gov.sg/newsroom/press-replies/2017/0224-foreign-worker-salarydisputes-are-dealt-with-speedily> accessed 31 May 2019.

- - 'Key Facts on Work Permit for Foreign Worker' (2018) $<$ http://www.mom.gov.sg/passes-and-permits/work-permit-for-foreign-worker/keyfacts> accessed 31 May 2019. 
South Korea Ministry of Employment and Labor, 'Overview: Procedure on Selection and Introduction of Foreign Worker (E-9)' (2015) $<$ https://www.eps.go.kr/ph/index.html> accessed 31 May 2019.

Surak K, 'Guestworkers: A Taxonomy' (2013) 44 New Left Review 84.

Testaverde $\mathrm{M}$ and others, Migrating to Opportunity: Overcoming Barriers to Labor Mobility in Southeast Asia (World Bank 2017).

Weiss M, 'Re-Inventing Labour Law?', The Idea of Labour Law (Oxford University Press 2011).

Zou M, 'The Legal Construction of Hyper-Dependence and Hyper-Precarity in Migrant Work Relations' (2015) 31 The International Journal of Comparative Labour Law and Industrial Relations 141. 